Vol 2. No 1. Februari 2018

ISSN 2580-5029

\title{
PENGARUH PEMBERIAN EKSTRAK BUAH PISANG (Musa acuminate L) DAN BUAH ALPUKAT (Persea americana Mill) TERHADAP BERAT HATI MENCIT (Mus musculus) BETINA
}

\author{
Heny Utami Ningsih ${ }^{*}$, Ulfa Wafirotul Bahiyyah ${ }^{1}$, Risa Purnamasari1 \\ 1Universitas Islam Negeri Sunan Ampel, Surabaya, Indonesia \\ *Email: henyutami07@gmail.com
}

\begin{abstract}
The liver is one of the four major organs that eliminate toxins from the body and plays several roles in detoxification. The aim of this study is to determine the effect of banana extract (Musa acuminate $L$ ) and avocado (Persea americana Mill) to mice liver weight (Mus musculus). A total of 24 female mice were used in this study. The mice were divided into 4 groups. P1 was the untreated group (control), P2 was the group given with the banana extract, P3 was the group given with the avocado and P4 was the groups that are given banana extract and avocado extract. The extract was given with oral at the appropriate dose for 5 days. The mice were dissected and the liver was taken to be weighed. The data obtained were analyzed statistically. From the research results that the addition of banana and avocado extract did not increase significantly liver weight (P1=13.5, $P 2=13.5, P 3=9.0, P 4=13.4)$ but increased significantly on body weight the highest is P2 group (P2=17.6). The results showed that there was no significant difference in the control group with the treatment groups. It shows that there is no effect of addition banana and avocado extract to liver weight of mice but it affects to the body weight.
\end{abstract}

Keywords: Banana (Musa acuminate L), Avocado (Persea americana Mill), Mice (Mus musculus), liver weight.

\begin{abstract}
ABSTRAK
Hati merupakan satu dari empat organ utama yang menghilangkan toksin dari tubuh dan memainkan beberapa peran dalam detoksifikasi. Penelitian ini bertujuan untuk mengetahui pengaruh pemberian ekstrak buah pisang (Musa acuminate L) dan buah alpukat (Persea americana Mill) terhadap berat hati mencit (Mus musculus). Sebanyak 24 ekor mencit betina digunakan dalam penelitian ini. Mencit tersebut dibagi menjadi 4 kelompok. P1 adalah kelompok kontrol yang tidak diberi perlakuan, P2 di beri ekstrak buah pisang, P3 di beri ekstrak buah alpukat dan P4 di beri ekstrak buah pisang dan alpukat. Selanjutnya ekstrak diberi secara oral dengan dosis sesuai berat badan selama 5 hari. Kemudian mencit dibedah diambil organ hatinya lalu ditimbang. Data yang diperoleh dianalisis secara statistik. Dari hasil penelitian bahwa penambahan ekstrak pisang dan alpukat tidak meningkatkan berat hati secara signifikan $(\mathrm{P} 1=13,5, \mathrm{P} 2=13,5, \mathrm{P} 3=9.0, \mathrm{P} 4=13,4)$ namun meningkatkan berat badan kelompok paling besar pada P2 $(\mathrm{P} 2=17,6)$ secara signifikan. Hal tersebut menunjukkan tidak terdapat pengaruh pemberian ekstrak terhadap berat organ hati mencit, tapi berpengaruh pada berat badan.
\end{abstract}

Kata Kunci: Buah pisang (Musa acuminate L), buah alpukat (Persea americana Mill), mencit (Mus musculus), berat organ hati. 


\section{PENDAHULUAN}

Hati adalah organ kelenjar terbesar dengan berat kira-kira 1200-1500 gram. Terletak di abdomen kuadrat kanan atas menyatu dengan saluran bilier dan kandungan empedu. Hati menerima pendarahan dari sirkulasi sistemik melalui arteri hepatica dan menampung aliran darah dari sistem porta yang mengandung zat makanan yang diabsorbsi usus. Secara mikroskopis, hati tersusun oleh banyak lobules dengan struktur serupa yang terdiri dari hepatosit, saluran sinusoid yang dikelilingi oleh endotel vaskuler dan sel kupffer yang merupakan bagian dari sistem retikuloendotelial (Rosida, 2016).

Hati memiliki peran sangat penting dalam metabolisme glukosa dan lipid, membantu proses pencernaan, absorbs lemak dan vitamin yang larut dalam lemak, serta detoksifikasi tubuh terhadap zat toksik.

Buah pisang (Musa acuminate L) mengandung tannin, alkaloid, saponin dan flavonoid (Eleazu, Okafor dan Ahamefuna, 2010). Buah pisang (Musa acuminate L) juga diketahui memiliki kandungan glikosida (Ajani et al., 2010).

Buah pisang juga mengandung kalium. Kalium bermanfaat untuk mengendalikan tekanan darah, ter-api darah tinggi serta membersihkan karbondioksida di dalam darah. Selain kalium, buah pisang juga mengandung tembaga $(\mathrm{Cu})$ dan seng $(\mathrm{Zn})$ yang berperan penting sebagai antioksidan untuk menangkal radikal bebas.

Flavonoid pada buah pisang yang berperan se-bagai antioksidan memiliki banyak manfaat dalam pengobatan salah satunya sebagai antihiperlipidemia. Mekanisme flavonoid sebagai antihiperlipidemia ialah dengan menghambat oksidasi LDL dan meningkatkan aktivitas enzim lipoprotein lipase (Nugroho dkk, 2016).

Buah alpukat (Persea americana Mill) juga memiliki beberapa kandungan kimia. Kandungan kimia yang terdapat dalam buah alpukat adalah sap-onin, alkaloid, flavonoid, tannin, asam folat, asam pantotenat, niasin, vitamin dan mineral. Kandungan serat dan asam lemak tak jenuh tunggal (MUFA) dalam buah dapat menurunkan kadar trigliserida dan kolesterol tinggi dalam darah. Bersama dengan vita-min $\mathrm{C}$, vitamin $\mathrm{E}$ dan glutation, asam lemak tak jenuh tunggal dapat melindungi pembuluh darah arteri dari kerusakan oleh adanya timbunan LDL. Niasin bekerja mempengaruhi aktivitas enzim lipoprotein lipase yang mengakibatkan penurunan produksi VLDL di hati yang berakibat penurunan kolesterol total, kolesterol LDL dan trigliserida. Selain itu niasin ini juga dapat meningkatkan HDL (Dalimartha, 2008).

Berdasar pada banyak manfaat yang dikandung oleh buah pisang dan buah alpukat maka penelitian ini dilakukan untuk mengetahui efek kedua buah tersebut 
dengan menghitung dari berat organ hati yang dimana organ hati merupakan organ detoksifikasi terhadap zat toksik, sehingga dapat dijadikan referensi bahwa buah tersebut tidak menyebabkan toksik terhadap tubuh. Selain itu, buah pisang maupun alpukat memiliki banyak kandungan nutrisi yang dibutuhkan oleh tubuh sehingga dalam penelitian ini pertambahan berat badan mencit juga diamati karena nutrisi berpengaruh terhadap metabolisme tubuh dalam mendukung pertumbuhan.

\section{METODE}

\section{Alat dan Bahan}

Penelitian Pengaruh Ekstrak Buah Pisang Cavendish (Musa acuminate L) dan Alpukat (Persea americana Mill.) terhadap Berat Hati Mencit (Mus musculus) Betina ini dilakukan di Laboratorium Terintegrasi UIN Sunan Ampel Surabaya pada bulan Desember 2016. Adapun alat dan bahan yang digunakan meliputi:

Alat: baki stainless steel, spatula, gelas beker, pisau, talenan, oven, blender, kertas saring, pengaduk, kompor, evaporator, spuit 1cc, jarum sonde, papan bedah, alat bedah, timbangan digital, timbangan analitik, gelas arloji, hot plate stirer dan aluminium foil.

Bahan: buah pisang Cavendish (Musa acuminate L), buah alpukat (Persea americana Mill), mencit (Mus musculus) betina sebanyak 24 ekor berumur 8-10 minggu yang diperoleh dari PUSVETMA, methanol, aquadest, saline.

\section{Aklimatisasi Hewan Coba}

Mencit (Mus musculus) betina berumur 2 bulan diukur berat badannya sebelum dan sesudah di injeksi. Kemudian ditempatkan ke dalam kandang, tiap kandang diisi 6 ekor mencit (Mus musculus) betina. Mencit (Mus musculus) diberi pakan voer 925 dan diberi minum akuades. Selanjutnya ditempatkan ke dalam ruangan dengan pencahayaan 12 jam siang dan 12 jam gelap selama 3 hari kemudian diberi perlakuan ekstrak.

\section{Pembuatan Ekstrak Buah Pisang} Cavendish (Musa acuminate L) dan Buah Alpukat (Persea americana Mill)

Buah pisang Cavendish (Musa acuminate L) dan alpukat (Persea americana Mill.) diperoleh dari Puspa Agro, selanjutnya dikupas kulitnya menggunakan pisau kemudian dipotong tipis. Setelah itu diletakkan dalam baki stainless yang telah diberi alumunium foil dan di oven dengan suhu $80^{\circ} \mathrm{C}$ selama 12 jam sampai mengering untuk menghilangkan kandungan air didalamnya. Masingmasing dihaluskan dengan blender untuk mendapatkan serbuk.

Metode yang dipakai adalah maserasi, yaitu dengan merendam kedua serbuk yang telah dihaluskan masing-masing, pisang 97,5 gram dan alpukat 108,6 gram kemudian ditambahkan metanol sebanyak $400 \mathrm{ml}$ dengan perbandingan 1 (serbuk kasar) : 4 (metanol) di dalam gelas beaker. Perendaman dilakukan sambil diaduk dengan magnetic stirer sampai benarbenar 
Biotropic 2018. 2 (1):61- 66

Pengaruh Pemberian Ekstrak Buah Pisang (Musa Acuminate L) Dan Buah Alpukat (Persea Americana Mill) Terhadap Berat Hati Mencit (Mus musculus) Betina

homogen pada suhu ruang selama 30 menit.

Setelah itu disaring dengan kertas saring.

Hasilnya diuapkan dengan rotary evaporator dengan suhu pemanasan $80 \mathrm{oC}$ dan kecepatan 100rpm sampai diperoleh ekstrak yang kental. Hasil ekstraksi disimpan dalam lemari pendingin dengan suhu $4^{\circ} \mathrm{C}$.

\section{Kelompok Perlakuan}

24 ekor mencit betina (Mus musculus) dibagi menjadi 4 kelompok dengan jumlah 6 ekor pada setiap perlakuan :

1. Kelompok P1 (Kontrol): kelompok kontrol hanya di beri aquades atau saline.

2. Kelompok P2: kelompok perlakuan yang di beri ekstrak metanol buah pisang (Musa acuminate $\mathrm{L}$ ).

3. Kelompok P3: kelompok perlakuan yang di beri ekstrak metanol buah alpukat (Persea americana Mill).

4. Kelompok P4 : kelompok perlakuan yang di beri ekstrak metanol buah pisang (Musa acuminate L) dan alpukat (Persea americana Mill).

\section{Tahap Pemberian Ekstrak Buah Pisang} Cavendish (Musa acuminate L.) dan Buah

\section{Alpukat (Persea americana Mill)}

Mencit diinduksi ekstrak secara oral menggunakan spuit $1 \mathrm{cc}+$ jarum sonde sebanyak berdasar pada berat badan tiap mencit per $0.2 \mathrm{~mL}$ aquades setiap hari selama 5 hari. Perhitungan kadar induksi ekstrak dapat dilakukan menggunkan rumus konversi berat badan manusia ke mencit :

$$
\frac{B b}{20} \times 5.6=m g / 0.2 m L
$$

\section{Keterangan:}

1. Bb: Berat badan mencit (berbeda setiap mencit)

2. mg: Jumlah ekstrak yang diinduksikan (mg) yang nantinya dilarutkan per $0.2 \mathrm{~mL}$ aquades

\section{Analisis Statistik}

Pada penelitian ini digunakan uji statistik anova satu arah (One Way ANOVA)SPSS 16.0.

\section{HASIL DAN PEMBAHASAN}

\section{Hasil}

Setelah 3 hari aklimatisasi maka induksi mu-lai dilakukan berdasar pada kelompok perlakuan. Hasil pengamatan untuk berat hati pada semua kelompok selama 5 hari perlakuan induksi ekstrak dapat dilihat pada Tabel 1. Hasil rata-rata hubungan antara berat organ hati dan berat ba-dan pada mencit betina setelah pemberian ekstrak buah pisang Cavendish (Musa acuminate L) dan ekstrak buah alpukat (Persea americana Mill) ditampilkan pada Gambar 1. 
Biotropic 2018. 2 (1):61- 66

Pengaruh Pemberian Ekstrak Buah Pisang (Musa Acuminate L) Dan Buah Alpukat (Persea Americana Mill) Terhadap Berat Hati Mencit (Mus musculus) Betina

Sumber: Dokumentasi Penelitian, 2017

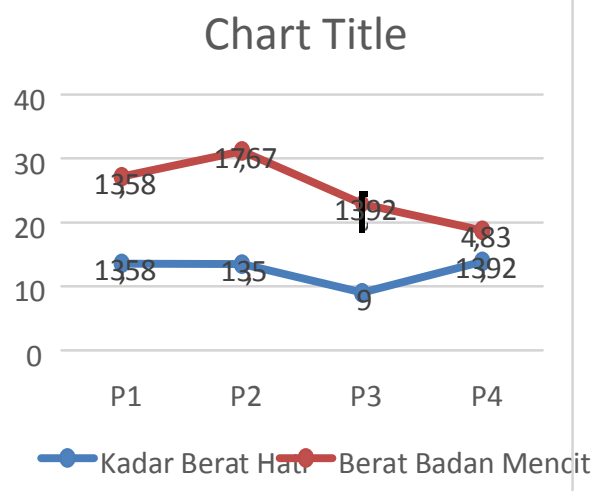

Gambar 1. Hubungan antara berat hati

Tabel 1. Pengaruh berat hati mencit setelah pemberian ekstrak buah pisang Cavendish dan ekstrak buah alpukat.

\begin{tabular}{|c|c|c|c|c|c|c|c|c|}
\hline \multirow{2}{*}{ Sampel } & \multicolumn{6}{|c|}{ Berat hati Mencit (gr) } & Jumlah & Rerata \\
\cline { 2 - 9 } & $\mathbf{l}$ & $\mathbf{2}$ & $\mathbf{3}$ & $\mathbf{4}$ & $\mathbf{5}$ & $\mathbf{6}$ & $\mathrm{gr})$ \\
\hline P1 & 1.12 & 1.52 & 1.50 & 1.36 & 1.21 & 1.28 & 7.99 & 1.33 \\
\hline P2 & 1.64 & 1.32 & 1.31 & 1.20 & 1.38 & 1.15 & 8 & 1.33 \\
\hline P3 & 0.98 & 0.97 & 1.62 & 1.19 & 1.05 & 1.44 & 7.25 & 1.20 \\
\hline P4 & 1.44 & 1.26 & 1.60 & 1.28 & 1.09 & 1.44 & 8.11 & 1.35 \\
\hline
\end{tabular}

(Sumber: Dokumentasi Penelitian, 2017)

\section{Pembahasan}

Berdasarkan Gambar 1 didapatkan bahwa berat badan mencit pada semua kelompok perlakuan meningkat, dibanding dengan kelompok kontrol. Ini dapat terjadi karena pertambahan berat badan pada suatu individu dipengaruhi antara lain oleh faktor nutrisi. Nutrisi pada dasarnya adalah nutrient atau zat gizi yang terdapat dalam pakan yang masuk ke dalam tubuh individu sebagai konsumsi pakan, sehingga pada penelitian ini berat badan pada mencit kelompok perlakuan meningkat akibat tersedianya nutrisi yang terkandung dalam ekstrak buah pisang Cavendish (Musa acuminate L) dan ekstrak buah alpukat (Persea americana Mill).

Pada penelitian ini organ yang dilihat perubahan beratnya adalah organ hati, karena organ hati merupakan organ yang penting dalam metabolisme, detoksifikasi, penyimpanan dan ekskresi xenobiotik dan metabolitnya. Selain itu organ hati rentan terhadap kerusakan akibat metabolit yang bersifat toksik (Brzoska et al., 2003).

Hasil analisis secara statistik menunjukkan bahwa tidak terdapat perbedaan yang signifikan berat organ hati mencit kelompok kontrol dengan semua kelompok perlakuan. Hal tersebut menunjukkan bahwa dengan pemberian ekstrak buah pisang (Musa acuminate L) dan buah alpukat (Persea americana Mill) tidak menyebabkan kerusakan pada hati mencit. Artinya senyawa pada kedua ekstrak tersebut tidak bersifat toksik.

\section{SIMPULAN}

Pada penelitian ini, dapat disimpulkan bahwa pemberian ekstrak buah pisang dan buah alpukat tidak memberikan pengaruh pada berat organ hati mencit tetapi berpengaruh positif terhadap berat badan mencit. Perlu dilakukan penelitian lebih lanjut secara histopatologi organ hati mencit. 


\section{DAFTAR PUSTAKA}

Adiwijaya, S. 2012. Kamus Biologi Lengkap. Surabaya: CV. Putra Kaya.

Brzoska, M. 2003. Liver and Kidney Function and Histology in Rats Exposed to Cadmium and Ethanol. 38 (1): 2-10.

Rohmatin. 2014. Kerusakan Sel Hep-ar Tikus Putih Jantan (Rattus norvegicus) yang diinduksi Karbon Tetraklor-ida (CCl4) setelah Diberi Ekstrak Eta-nol Bawang Dayak (Eleutherine palmi-folia Merr.). Jurnal Histopatologi. (2): 1-6.

Campbell. 2010. Biologi jilid 3. Jakarta. Erlangga.

Haryo P., Inna., Iriani. 2015. Struktur Hati Mencit (Mus Musculus L.) Setelah Pemberian Ekstrak Daun Kaliandra Merah (Calliandra calothyrsus Meissn.). Jurnal Simbiosis III. (1): 258268.

Wayan., Ngurah A., Ni Wayan. 2014. Histologi Hati Mencit (Mus musculus L.) yang Diberi Ekstrak Daun Lamtoro (Leucaena leucocephala). Jurnal Simbiosis II. (2): 226-235. 